Slavica Troskot

University of Zadar

\title{
Pacific Ocean Experience as a "Different Optic" of Hawaiian Literary History \\ (Floating between Asian American and Pacific Studies)
}

This article focuses on the regional, local and oceanic aspects of Hawaiian literature proposing that its value might be interesting for the understanding of the heterogeneity of the American project. Literary voices from these islands are randomly discussed within the Asian American Studies or Pacific Studies projects. The author hereby proposes that the literary history of these islands might be useful for research in cultural human geography, giving us a better understanding of the concepts of island, sea, and ocean, as well as for the comprehension of the role of the economy in the development of the regions of the United States. An oceanic approach in this sense might be of value if introduced more thoroughly into the agenda of American cultural and literary research. As a meeting point between East and West this archipelago is situated at the crossroads of the modern trade routes of the Pacific Rim and therefore its literary production might offer an interesting insight into the understanding of the contemporary world.

Key words: American Studies, oceanic approach, Hawaiian literature, Pacific history, literary cartography

Generally speaking, contemporary Hawaiian literature represents an exotic and at least triple mixture, that of East, West and native Polynesian voices. An understanding of the writing of Hawaiian local authors requires historical insight into the development of the islands before and after their entrance into modernity. Official western history of this archipelago begins 
with its discovery by James Cook for the British Crown, which marked the beginning of the end of the Stone Age for the islanders. The changes that followed were deep and ruthless for the indigenous population. Politically independent but economically and culturally overpowered by the new settlers, by the end of the nineteenth century these islands became territory of the rising new world power, the United States. In the course of the twentieth century, as the American project was reaching its position at the center of a new world order, Hawaii found its place as the official fiftieth star of the Union flag. The only island state, it was always a different and seemingly far-away Pacific paradise. Yet, reading this literature leads to many different and less paradisiacal conclusions.

The aim of this article is to enter the fiction of old and modern literary Hawaii through a proposed reading of the notions of island, sea, and ocean as somewhat neglected concepts in cultural human geography. The article will also try to comprehend the meaning of this region for the development of the American project. Besides, since the country's economic and military focus has been changing recently, and the Pacific Rim is leading in the game of world trade and exchange of goods and capital (Wilson 391), it might be interesting to question and analyze the possibility of reading the economy and the American project through the literature that has been written in the very center of what is still the American Pacific. Sporadic criticism of this literature can be found within Asian American Studies or as a part of Pacific Studies, but we will try to prove, drawing from Grgas and Dvorak, and their proposals of an oceanic and heterogeneous approach to American Studies, that Hawaiian literature - native, settler or immigrant - rightfully belongs to its own oceanic Hawaiian-American niche.

Founding our argument in the real-life oceanic economy and its importance for the United States, we will focus our attention on Hawaii, the only oceanic state. Hawaiian literature is burdened with the different histories of its peoples, their voyages, generations who have travelled, lived, migrated across the Pacific, from continents to islands and back, and from islands to islands. We will try to pinpoint how useful these different histories and stories 
might be for the understanding of literature, the human geography of the sea, and furthermore we will try to approach this literature in the contemporary world as possible literary cartography valuable for American Studies. The article does not focus on specific work of fiction but merely tries to set a course for the proposed kind of literary navigation.

\section{Oceans and the United States}

As Stipe Grgas suggests in his book in the chapter entitled "Oceanic Space in American Studies," (published in Croatian in 2014), the role of the oceans in the formation of American history and the impact they had on the economic and military development of American exceptionalism have not been appropriately considered (254-68). In an unpretentious attempt to offer one possible reconsideration of the oceanic approach within the agenda of American Studies it may be useful to borrow from the discipline of geography by quoting the Routledge Handbook of National and Regional Ocean Policies, from the chapter "Development of a National Ocean Policy in the United States":

The United States is a major maritime nation. Its ocean and coastal areas are priceless assets that support the nation's economy, security, health and well-being, and long-term resilience. The United States claims an exclusive economic zone (EEZ) of 11.5 million $\mathrm{km} 2$ - the world's largest (FAO, 2005). The US EEZ is 25 per cent larger than the US land mass area of 9.2 million $\mathrm{km} 2$, and its coastline extend for $19.924 \mathrm{~km}$ (CIA, 2014). The oceans and coasts of the United States directly support marine transportation, fisheries and aquaculture, energy production, recreation, biotechnology, and other uses. US coastal shoreline counties (including the Great Lakes) accounted for 41 per cent of the nation's gross domestic product (GDP) in 2010. This economic activity contributed about 44 million jobs and US\$2.4 trillion in wages (NOAA, 2012). While these figures certainly matter, it is important to consider that these are only the market values of ocean and 
coastal resources. The non-market values, such as that of public access to the beach or unobstructed ocean-view, are estimated at over $\$ 100$ billion a year (NOEP, undated). Further, it is becoming increasingly clear that the services that these ecosystems provide, including coastal storm protection, carbon sequestration, and the regulation of climate, natural hazards disease, wastes and water quality, are of significant value that has not yet been captured (NOAA, undated). Ocean and coastal ecosystems and sectors are clearly a vital part of the US economy. (Cicin-Sain et al. 311)

Relying on the logic of economy and trade and the importance of the oceans and the sea for the United States, we should have in mind that both the Atlantic and the Pacific obviously had - and still have — significant effect on historical development as well as on contemporary political and strategic developments (Grgas 2014: 263, 267). Out of this comparative insight, a distinction emerges indicating that the Atlantic Ocean is somewhat more visible within English studies as a result of the research on the slave trade, the Middle Passage and the influence of the British naval empire. On the other hand the Pacific Ocean is significantly less visible in English studies and for the most part remains out of academic focus. The following theoretical examples indicate that a shift of focus is taking place.

In 2015, Greg Dvorak suggested in his article "Oceanizing American Studies" that a "shift from continental to oceanic thinking in and of itself is a valuable way to rethink our approaches not only to the United States of the Pacific but to the entire world" (616). The Pacific perspective is not merely a project of cultural decolonization, it also proposes "a completely different optic ... about our heterogeneous water planet" (616). Dvorak argues that for American Studies, "Oceanian awareness" might "positively conceive the heterogeneity of America itself" (616). Dvorak himself might be considered as an insider to the topic, since he lived in the Marshall Islands; his father also lived there, where he worked in the American military establishments (609).

Stipe Grgas proposes something similar for the American Studies agenda in his book Američki studiji danas: identitet, kapital, spacijalnost (Amer- 
ican Studies Today: Identity, Capital, Spatiality) stating that the real historical and economic sweep of the United States' global, military and economic power cannot be completely understood if we approach the American project as merely a history of the continental conquest or discovery (2014: 263). In that sense, the oceanic approach would provide the necessary and inevitable insight in the less visible yet highly productive Pacific area as the source of power and domination.

One additional but no less important aspect should be clarified for this "different optic," and again drawing from Grgas, human spatiality and human geography seem to have missed the real importance of the sea and the oceanic experience for the understanding of how the wheels of history and real-life economy are turning (2008: 96). In The Encyclopedia of Human Geography, edited by Barney Warf, there is no mention of the island, the ocean or the sea in the List of Entries (vii-xv). Although the history of the modern world was marked by navigation and maritime discoveries, there is no mention of these concepts either, except partially within other entries. Another Encyclopedia of Human Geography by Gerald R. Pitzl has the same lack in the entries, although there is one that may be of crucial relevance for the optic that we hereby propose. The relevance of the Pacific Ocean is noticed in the concept of Pacific Rim economic region:

This expansive region is experiencing rapid economic growth, and every country has developed significant worldwide trading connections. An important shift is underway on the global economic scene. Europe was the leading economic center in the nineteenth century during the heyday of the Industrial Revolution (emphasis by Pitzl, 2004). Leadership passed to North America in the twentieth century as the U.S. economy grew rapidly. The twenty-first century may see the Pacific Rim emerge as the most affluent economic region of the world. (171)

Relying firstly on this argument, and secondly on the proposal of the heterogeneous approach, suggested by Dvorak as well as by Grgas (2014) 
that the United States is not merely an exceptionalist continental project, while thirdly taking into consideration what Cicin-Sain et al. elaborate on the economic and geographic importance of the oceans in American life we propose that the regional oceanic approach might be appropriate and mean-

ingful. The Pacific oceanic region in that sense, with its literary renderings of the sea and the ocean, might be interesting for American Studies as a relevant segment for the understanding of the complexity of the American project. In the middle of the Pacific Ocean and at the crossroads of Pacific Rim trade routes, there lies the archipelago that is the fiftieth state of the Union, Hawaii.

\section{"Crossroads of the Pacific"}

Discovered in 1778 by James Cook on his third and last voyage around the world, these islands, Hawai'i nei, have had an interesting history. Today they represent the spectacular and unique meeting place of East and West. According to Ralph S. Kuykendall and A. Grove Day: "[T] he vast Pacific Ocean is the most prominent geographical feature of our Earth. Scattered in this ocean, which occupies a third of the surface of the globe, lie the Hawaiian Islands, the 'Crossroads of the Pacific" (3). An additional remark by the same authors may be useful for the perspective of this faraway archipelago, "It was an accident that Hawaii was the last important Pacific island group to be discovered by voyagers from the outer world; but it was no accident that Hawaii because of its strategic position, was the first to achieve modernity" (v). If we consider the location and the importance of these islands, the question emerges on the role of the Hawaiian history in the development of the American project.

In less than two hundred and fifty years of dynamic history, these islands have been changing in such a rapid way as a result of the undeniable fact that their development followed the logic of capitalist development to the utmost. The economy of Hawaii depended in different phases on the trade with newcomers, the sandalwood trade, whaling, mono-cropping agriculture, sugar cane, pineapple and coffee plantations, the development of the American 
military bases, and, finally, tourism in every aspect of island life. Those less attractive episodes of the history of the Pacific paradise remained hidden from the mainstream headlines. Modernity did not come in an easy manner. It carried with itself the burden of land appropriation, the breaking of the old kapu (taboo), the importation of coolies from Asian countries, heavy labor, hunger, personal and familial disappointments, plague, leprosy, racism, racialized labor, forced abolition of the monarchy, annexation, destruction in World War II, postwar militarization, and pollution. Today Hawaii is a naval, military and economic outpost of the United States in the middle of the Pacific Rim.

The complexity of contemporary life and existence in the area is astounding and vibrant; therefore a simple division or juxtaposition into hegemonic/imperialist or native/decolonizing moment would be inconsistent and superficial. If two centuries ago William Ellis of the London Missionary Society was having interesting conversations with the Hawaiian priestess, the incarnation of Pele, the goddess of volcanoes (Bohls 490-94), today it would be impossible to go back to the roots and put aside the intensive and rapid changes in society, culture and geography. What makes this literature additionaly interesting is the representation of the island geography through the settlers', natives' and immigrants' relation to space, geography, soil, waterways, land division (Mahele), and the ways these are remembered and retold by old and by modern local Hawaiian writers. In an attempt to understand the real power of the contemporary United States, and having in mind that the Pacific will be, or already is, in economic focus, it might be useful to take into consideration the different oceanic optic, and for this, no other region of the U.S. offers a better platform for reflection.

\section{Hawaiian Literary Anarchistic Polyphony}

Research centers for the Pacific Islands can be found in Australia, Hawaii, New Zealand, France, and Japan (Firth 144-46). The Pacific and Hawaii can be randomly found within courses focusing on the Asian Pacific Amer- 
ican experience in research done by Victor Bascara, Susan Najita, Robert Diaz, and Erin Suzuki (Lee 101-11, 167-74, 175-88, 352-66). Hawaiian literary history seems to be floating somewhere between Asian American Studies and Pacific Studies. In Paul Lauter's Companion to American Literature and Culture, Shirley Geok-lin Lim argues that "[S]ome Americans ... continue to view Hawaii as not part of the United States" (515). Native American literary studies do not tend to include Hawaiian literary voices. Politically, Native Hawaiians are not Native Americans. Being a strategic outpost in the Ocean and directly facing the East, these islands will never be part of the mainland, not only in the geographical sense, but in the sense that their function is to be a faraway ocean base and an American center in the ocean facing the East.

Literary voices from this area are various, contradictory and complex. Considering the experiences of these territories, their different individual and collective views could, as proposed previously, be distinguished in terms of their native, settler and immigrant insights. All of these three perspectives have local grounding, and out of these positions, the last less than two hundred and fifty years of modern history, in this distant and seemingly isolated archipelago, look like a time laboratory within which different histories have been told, chanted, recorded, forgotten, invented, written, retold, remembered, and conceptualized. The voices of different nations, races, cultures and continents have crisscrossed and found their place in vibrant and multilayered Hawaiian fiction.

The nineteenth century reflected the voices of the newcomers, settlers, missionaries, traders, and economic conquerors. American and British writers who wrote about Hawaii and the Pacific were mostly cultural outsiders like Mark Twain, Robert Louis Stevenson, Jack London, Charles Warren Stoddard, and Herman Melville. Less known, but also published in the same century were books by Hawaiian King David Kalakaua (The Legends and Myths of Hawaii) and by Queen Liliuokalani (Hawaii's Story by Hawaii's Queen), both in the English language. What marks Hawaiian literature from its beginnings are the multiple visions of stories and histories as told by different races and cultures. 
Although discovered and named the Sandwich Islands by James Cook for the British Navy, Hawai'i nei were never part of the British Empire. The Islands were unified under the leadership of the King Kamehameha I and functioned as a monarchy with written constitution until 1898, when they were annexed by the United States. What lurked behind political independence and what changed the course of history was their economic dependence on the world trade system, whaling, agriculture, labor, and production. Once contact with the Europeans was established, there was no possibility to escape the economic changes and consequences that contact brought. Those who forced Queen Liliuokalani to abdicate were a group of white Hawaiian merchants, plantation owners, and descendants of missionaries, who lived in the Islands and whose trade dictated the development of society, the island economy, and the complete way of life. The overthrow was a successful attempt to protect the financial and economic interests of the owners of the sugar industry (Daws 2009: 7-32). The same was the reason for the inflow of the cheap Asian labor force. Histories of this kind are told and retold in novels by contemporary Hawaiian writers like Kiana Davenport. When the Islands became the fiftieth state of the Union in 1959, the celebration was followed by the publication of James Michener's grandiose historic novel $\mathrm{Ha}$ wai'i. Although referring to different periods of Hawaiian history, Michener's epic-like, celebratory view bears the mark of the dominant American stream of history and greatly differs in tone from later fiction on native topics by Davenport, whereas the revitalization of subordinate histories and memories of Asian immigrants and descriptions of life and work on the plantations started with Milton Murayama.

The nineteen-seventies brought the revival of different cultural voices. According to Stewart Firth in his article "Future Directions for Pacific Studies", "Pacific Studies in Hawaii ... are mostly conceptualized as projects of cultural Renaissance, in which the aim is to reclaim and reassert cultural identity" (147). A similar topic is analyzed by Susan Najita in her study Decolonizing Cultures of the Pacific. Eric Chock of Bamboo Ridge Press identifies local Hawaiian literature as "Modern Hawaiian Literary Tradition" re- 
fusing to accept mainland culture and literature as the norm (7). Ku'ualoha Ho'omanawanui writes about Kanaka Maoli (Native Hawaiian) empowerment through literature. There are also those who write for the political protection and preservation of native culture, like Haunani Kay Trask, Noenoe Silva, and Rona Tamiko Halualani.

Important Hawaiian fiction writers today, besides those already mentioned, include Lois Ann Yamanaka, Kaui Hart Hemming, Rodney Morales, Nora Okja Keller, Chris McKinney, Graham Salisbury, and Gary Pak. Be that as it may, the literary production of these islands reflects interesting histories of the American age in the Pacific. The literary texts of, as Chock puts it, the "Modern Hawaiian Literary Tradition" reveal not only the histories and experiences of the local population, their hopes, dreams, fears, failed expectations, and more or less successful pursuits of happiness; more than just reflecting on the lives of the islanders, contemporary literature as well as early American and Hawaiian voices from the Pacific constitute maps of the invisible ocean histories, a cartography of travels across the largest of oceans. We hereby try to suggest that in this fiction is inscribed an interesting literary cartography that could be perceived as the experiences of the island, the sea and the vast ocean. A reading of Hawaiian literature in this "different optic" might be a useful contribution to the understanding of the human geography of islands, the history of the American Pacific, and its economic and cultural development as well as of the role that the Hawaiian archipelago has had in the formation of the power of the United States and continues to have in the future of the Pacific Rim.

Before we continue with the aim to pinpoint certain crucial elements of the hereby proposed mapping of the Pacific in Hawaiian literature, it might be appropriate to mention that this type of reading literature does not intend to neglect different cultural and political appropriations of the Pacific or Hawaii, the settler culture with its imperial moments, the decolonizing aspects of the cultural survival of the native societies nor the voices of the immigrants who are seeking their own locality in the Hawaiian soil and sea. On the contrary, these different perspectives are extremely valuable as the initial points 
of entry into the proposed analysis. Also, this article is only an incomplete and superficial introduction to a possible topic that should be elaborated on a much larger range of reading. The texts and authors mentioned on these pages are but a few out of many who deserve critical attention in this direction. After condensing the meaning of the Ocean for the life and culture of the Unites States and the need to understand its only fully oceanic state through its literature, stories, and histories, let us now direct our argument towards the possible different meanings of terms the island, the sea and the ocean in different novels, stories, cultural representations, and myths of the Island literature.

\section{Literary cartography of the Rock'n'Sea}

To draw an initial frame for further discussion we have to refer to the human geography of islands and the contemporary position of Hawaii. Stephen Royle's book Geography of Islands (2001) is one of rare successful attempts to systematize the knowledge on world islands, including their geography, meaning, economic and political destinies, their development, and their different natural and cultural features. In the book he states that " $[S]$ mall places such as islands are usually powerless in political terms" (4) and that "the insular position . . . is one of powerlessness, dependency and insignificance" (134). The reasons for this, Royle argues, are "the unequal contestation between islands and outside forces" (4). According to Gavan Daws, the relations of power between the United States and Hawaii are the following: "twentieth century America, like it or not, was cast in an imperial role. She was a world power, with especially heavy commitments in the Pacific hemisphere, and Hawaii was an indispensable forward base” (Daws 1974: 386). Today, when discussing the Pacific military situation, Royle elaborates:

unlike the situation on Okinawa or the Philippines, there is no governmental pressure on the Americans to reduce their presence in the Hawaiian archipelago. There are some Hawaiian people who would wish for more indepen- 
dence, and there are movements such as Ka Lahui Hawaii which have this agenda, but Native Hawaiians make up only about 13 per cent of the total population. (146)

The undeniable fact remains that Hawaii is an American island state. From the perspective of a Native Hawaiian, Pilahi Paki, who remembered the days when, as a result of the American conquest, the histories of Native Hawaiians, their islands and their traditional ways of life were irrevocably transformed. The only thing that remains is hope that the remembrance of the old ways will at least be harbored in native people's memory as the last point of resistance under the civilizational overturn that they as people are painfully aware of: "'You will be living in the haole time, and the wise thing to do is to move with the time, because time is a thing that belongs to no one ... there's only one thing I ask of you, my children - You are Hawai' i, and I would appreciate that you remain Hawai'i' (Pilahi Paki 1910-1985)" (Noyes 67). The documentary voice of Noyes' collection attempts to maintain the remembrance of the traditional culture under the overwhelming political, economic, and historical influence of the American state over Native Hawaiian stories and histories.

If the islands were indeed paradise on Earth for the Native Hawaiians before their contact with Europeans, for Mark Twain, who remained forever enchanted with these islands, they were a big chance for America. For Stevenson and Jack London, this archipelago was a domain of romantic pursuit and the essence of the adventurous spirit. For Melville, the Pacific is a stage for trade, whale hunting, and human enterprise. The experience of the Asian coolies was the history of hard work, prison on the rocks, with an ocean of opportunity and a long distance from home, but their Pau Hana (finished working) helped develop the diversity (Takaki xi) of contemporary island life. Different perspectives of island history are mapped in the stories of immigrants from Japan, the Philippines, China, Korea, Spain, Portugal and other countries. The Hawaiian islands remember various histories: the history of cattle farms with "paniolos," Hawaiian cowboys; the history of capitalist de- 
scendants of American Boston missionaries; the history of lepers who were forced to live on Kalupapa peninsula of the Island of Molokai; the horrific memories of the World War II; the history of the victims of sexual slavery in Japanese war camps; the history of nuclear testing grounds; the rise of the tourist industry, and the struggle of the local population against pollution in this specific and limited ecosystem. All of these histories are marked by ocean travel, migration, and the repetitive movements of generations of travelers and can be found in local Hawaiian stories and novels.

Setting aside the more or less familiar concepts of island paradise or island as a prison, what remains valuable to explore is the old tradition of Polynesian sailors that travelled and navigated these waters a thousand years before James Cook. According to Melissa Nelson in her "Indigenous Science and Traditional Ecological Knowledge," "Pacific Islanders use traditional non-instrument wayfinding to navigate the entire Pacific Ocean using their observations of the star Canopus, other stars, and other natural signs like wind and wave patterns, to travel across the Pacific and arrive at small island nations" (199). The importance of the practical local knowledge in this sense is a kind of the specific island and ocean mapping. This form of oral cartography and this cognitive diversity enrich the importance of the situational knowledge; for hundreds of years Polynesian seascape was, according to Nelson, contained and memorized in "storyscapes" and "songscapes" (201).

The extreme vividness and concentration of events in this region rises the awareness that on these little specks of land, or as Epeli Hau'ofa names the Pacific region "A sea of islands" (Wood, 349) somewhat important courses of events were taking place, and that this vast watery area is extremely dynamic.

\section{The Value of the "Different Optic"}

Whether the property of kings or queens, a monarchy or a republic, Hawaii is the most remote archipelago in the largest of oceans. Based on that undeniable geographic position, even if politically changeable within the course of history, it is a challenge for the mind to understand the experiences 
of generations of people whose private individual or collective destinies are impregnated with this natural circumstance. No matter how useful cultural politics are, with its different ways of thinking, literary theories, political points of view, contemporary power issues, in spite of it all, it remains a challenge for the mind to do research in a triangle that consists of man, ocean/ island, and storytelling.

It would be a rare and priceless privilege for American Studies to incorporate this kind of thinking into its agenda, instead of leaving it to fluctuate between Asian American and Pacific Studies.

Instead of railways and visible roads being built, books and novels have been written that struggle to maintain the truth and history about the region above the surface of the ocean. It is surely worth exploring this literature resembling maps of remembrance, just like Polynesian hula chanting and dancing. If Polynesians were navigating these waters by following waves, clouds, winds and stars, then perhaps cultural and human geography is today written and preserved in written stories and novels by Hawaiians. In that sense American Studies and human geography can only gain from the inclusion of this different optic of the oceanic experience, explaining simultaneously many aspects of the American project and the invisible flow and circulation of capital, money, labor and goods across the Pacific Ocean, within the Pacific Rim.

\section{Works Cited}

Bohls, Elizabeth A. and Ian Duncan, ed. Travel Writing, An Anthology. Oxford UP, 2005.

Chock, Eric. "On Local Literature“. The Best of Bamboo Ridge, The Hawaii Writers'

Quarterly, edited by Chock \& Darrel H.Y. Lum, Bamboo Ridge P, 1986, pp. 6-9.

Cicin-Sain, Biliana, Gerhard F. Kuska, Caitlyn Snyder and Kateryna Wowk.

"Development of a National Ocean Policy in the United States." Routledge Handbook of National and Regional Ocean Policies, edited by Biliana Cicin Sain, David L. VanderZwaag, and Miriam C Balgos, Routledge, pp. 311-47. Published online 14 May 2015. Accessed 17 Feb. 2016. 
Daws, Gavan. Shoal of Time, A History of the Hawaiian Islands. U of Hawaii P, 1974.

---. "A Brief History of the Hawaiian Islands." The Illustrated Atlas of

Hawai'i, edited by O.A. Bushnell, Island Heritage Publishing, 2009, pp. 7-31.

Grgas, Stipe. "More kao mjesto ili prostornost mora." S ove strane beskonačnosti, filozofiranje $i$

more, edited by Petar Šegedin and Ozren Žunec, Demetra, 2008, pp. 93-116.

---. Americki studiji danas: Identitet, kapital, spacijalnost. Meandar Media, 2014.

Dvorak, Greg. “Oceanizing American Studies.” American Quarterly, vol 67, no. 3, 2015, pp. 609-17. Project Muse. Accessed 24 Feb. 2016.

Firth, Stuart. "Future Directions for Pacific Studies." The Contemporary Pacific, vol.

15, no. 1, 2003, pp. 139-48. Project Muse. Accessed 24 Feb. 2016.

Ho `omanawanui, Ku` ualoha. “Ha, Mana, Leo (Breath, Spirit, Voice): Kanaka Maoli

Empowerment through Literature." The American Indian Quarterly, vol 28, no. 1\&2, 2004, pp. 86-91. Project Muse. Accessed 24 Feb. 2016.

Kuykendall, Ralph S. and A. Grove Day. Hawaii, A History From Polynesian Kingdom to American Statehood. Prentice Hall, 1976.

Lee, Rachel C., ed. The Routledge Companion to Asian American and Pacific Islander

Writing. Routledge, 2014.

Lim, Shirley Geok-lin. "Narrating Terror and Trauma: Racial formations and

'HomelandSecurity' in Ethnic American Literature." A Companion to American

Literature and Culture, edited by Paul Lauter, Wiley-Blackwell, 2010, pp. 508-27.

Nelson, Melissa K. "Indigenous Science and Traditional Ecological Knowledge,Persistance in Place." The World of Indigenous North America, edited by Robert Warrior, Routledge, 2014, pp. 188-214. Published online 22 Dec. 2014. Accessed 17 Feb. 2016.

Noyes, Martha H. Then There Were None. Bess P, 2003.

Pitzl, Gerard R. Encyclopedia of Human Geography. Greenwood Publishing, 2004.

Royle, Stephen A. A Geography of Islands, Small Island Insularity. Routledge, 2001.

Takaki, Ronald. Pau Hana, Plantation Life and Labor in Hawaii 1835-1920. U of Hawaii P, 1984.

Warf, Barney, ed. Encyclopedia of Human Geography. Sage Publications, 2006.

Wilson, Rob. "Doing Cultural Studies inside APEC: Literature, Cultural Identity and Global/Local Dynamics in the American Pacific." Comparative Literature, 
vol. 53, no. 4, 2001, pp. 389 - 403. JSTOR. Accessed 15 Mar. 2012.

Wood, Houston. "Cultural Studies for Oceania." The Contemporary Pacific, vol. 15, no. 2, 2003, pp 340-74. Project Muse. Accessed 16 Mar. 2012. 